\title{
The Physico-Chemical Composition and Energy Recovery Potentials of Municipal Solid Waste Generated in Numan Town, North-Eastern Nigeria
}

\author{
Alkasim Abubakar1 ${ }^{*}$, Maigida H. Barnabas' ${ }^{1}$, Baba M. Tanko² \\ ${ }^{1}$ Department of Physics, Modibbo Adama University of Technology, Yola, Nigeria \\ ${ }^{2}$ Department of Mechanical Engineering, Federal Polytechnic Mubi, Mubi, Nigeria \\ Email: ^alkasimabbat@gmail.com
}

How to cite this paper: Abubakar, A., Barnabas, M.H. and Tanko, B.M. (2018) The Physico-Chemical Composition and Energy Recovery Potentials of Municipal Solid Waste Generated in Numan Town, North-Eastern Nigeria. Energy and Power Engineering, 10, 475-485.

https://doi.org/10.4236/epe.2018.1011030

Received: October 25, 2018

Accepted: November 16, 2018

Published: November 19, 2018

Copyright $\odot 2018$ by authors and Scientific Research Publishing Inc. This work is licensed under the Creative Commons Attribution International License (CC BY 4.0).

http://creativecommons.org/licenses/by/4.0/

\begin{abstract}
Numan is an urban center in Adamawa State North-Eastern Nigeria. Its waste characteristics are similar to other places in sub-Saharan Africa. In this paper, the physico-chemical characterization of municipal solid waste generated in Numan Town was carried out to estimate the electrical power to be generated from it. The solid waste types were observed to comprise of polythene (27\%), organic waste $(24.1 \%)$, plastic $(10.2 \%)$, textile $(13.2 \%)$, paper $(9.8 \%)$, glass (9.3\%) and metals (6.4\%). The moisture content as discarded and daily average solid waste generation rate are $16.49 \%$ and $0.583 \mathrm{~kg} / \mathrm{sec}$ respectively. The chemical formula with and without water was determined as $\mathrm{C}_{923.28} \mathrm{H}_{1632.60} \mathrm{O}_{258.28} \mathrm{~N}_{12.89} \mathrm{~S}$ and $\mathrm{C}_{923.28} \mathrm{H}_{2099.70} \mathrm{O}_{494.16} \mathrm{~N}_{12.89} \mathrm{~S}$ respectively. The suitability of the municipal solid waste as a possible source of electrical power was also considered. The energy content of the solid waste on ash free dry-basis was determined as $20861.48 \mathrm{~kJ} / \mathrm{kg}$. The estimated power generation per day using incinerating plant at an assumed efficiency of $25 \%$ was $3031.5 \mathrm{~kW}$.
\end{abstract}

\section{Keywords}

Municipal Solid Waste, Moisture Content, Energy Recovery,

Power Generation

\section{Introduction}

The waste in Numan has dramatically accelerated due to population growth, increased income and living standards, which have tremendously caused changes in the quality and quantity of waste generated for the past few decades [1]. Sastry 
states that "the rate of waste generation is an index of socio-economic development and economic prosperity of the region". Numan town lacks effective and proper means of collecting and disposing waste. This has resulted in littering of waste on the streets, around the culverts, inside the gutters and other unapproved dump sites. The wastes must be properly handled, stored, collected, processed and disposed to reduce the health risk they will pose to the general public, such as disease outbreak e.g. cholera, typhoid fever and other airborne related diseases [2] [3] [4]. The increasing volumes of waste being produced would not be a problem if garbage is viewed as resources and managed properly. But despite the heavy volume of waste generated, this place suffers power shortage due to over dependence on power supply from fossil fuel and the use of electric power generators.

Although the energy needs of man are met by the discovery of fossil fuel deposits, such deposits are limited in quantity. Exploration and production cost to make them commercially available are high. Our energy needs have also grown exponentially, corresponding with human population growth and technological advancement [5]. There is need to explore renewable energy as well as waste to energy so as to reduce over dependence on fossil fuel power generation which produces greenhouse gases and in turn depletes the ozone layer leading to global warming which is gaining greater acceptance in the scientific community. Appropriate utilization of municipal solid waste plays essential role in reducing greenhouse gases, thus reducing the impact on the atmosphere. Energy recovery from Municipal Solid Waste (MSW) can also reduce the amount of fossils fuels utilization. It can also reduce the amount of land needed for MSW disposal and undesirable emission from landfills to air and water [6]. MSW is actually a resource with huge potential in terms of material and energy recovery [7]. Waste to energy is one good option of alternative energy source. Waste-to-energy meets the two basic criteria for establishing what a renewable energy resource is-its fuel source (trash) is sustainable and indigenous [8]. The waste to energy industries has proven itself to be environmentally friendly solution to the disposal of municipal solid waste and the production of energy [9]. Combining waste management with waste energy recovery step from municipal solid waste can address the problems of solid waste management and partly the energy crisis [10].

The population growth and knowledge has brought high demand on sustainable power that is environmentally friendly. It is in this light that MSW is considered and found to be clean alternative source of power. Proper harnessing of MSW can generate reasonable quantity of electricity that can power communities or even small scale factories. Globally, so much effort is being channeled towards developing processing technologies to release the resource and economic value of residual wastes as population grows and the demand for best sustainable management of waste is needed [11].

Most of the literatures reviewed in Nigeria [3] [12] and [13] deals with the 
Energy recovery from house hold solid wastes only and not the municipal waste. The few that works on the municipal solid wastes [2] [5] and [14] confined their works to their localities while this work extends to Numan a town in North-Eastern Nigeria.

The uncontrolled influx of people to the urban areas has brought about increase in the demand on electricity and increases the waste dumped in the municipality. This made businesses and socio-economic development of Numan metropolis to suffer many setbacks. Effective utilization of solid waste for energy generation will help curb the menace of environmental pollution and also lessen the effect of the epileptic power supply from the Power Holding Company of Nigeria (PHCN) on socio-economic development. In some cities these power outage lasts for hours leading to loses in the daily routines and productivity. This work examines the energy recovery potentials of the waste streams of Numan municipal area by sorting and preprocessing the combustible components of municipal solid waste and to determine their waste compositions and chemical characteristics. The calorific value of municipal solid waste was evaluated by obtaining the ultimate analysis or the elemental compositions and there after the "as discarded basis method" was used to obtain the energy content.

\section{Numan Metropolis}

Numan town lies on port of the Benue River, Adamawa State, Nigeria. It is located about 30 miles $(50 \mathrm{~km})$ from Yola the state capital. The indigenous people are called Bachama. Numan is situated at $9.47^{\circ} \mathrm{N}$ latitude, $12.03^{\circ} \mathrm{E}$ longitude and $137 \mathrm{~m}$ elevation above the sea level (Figure 1). Numan town, have about 77,617 inhabitants as at 2013 population estimate. The estimated waste generated by Numan populace is $50451.05 \mathrm{~kg} /$ day based on the $0.65 \mathrm{~kg} / \mathrm{cap} /$ day based on a research done on Yola by [15].

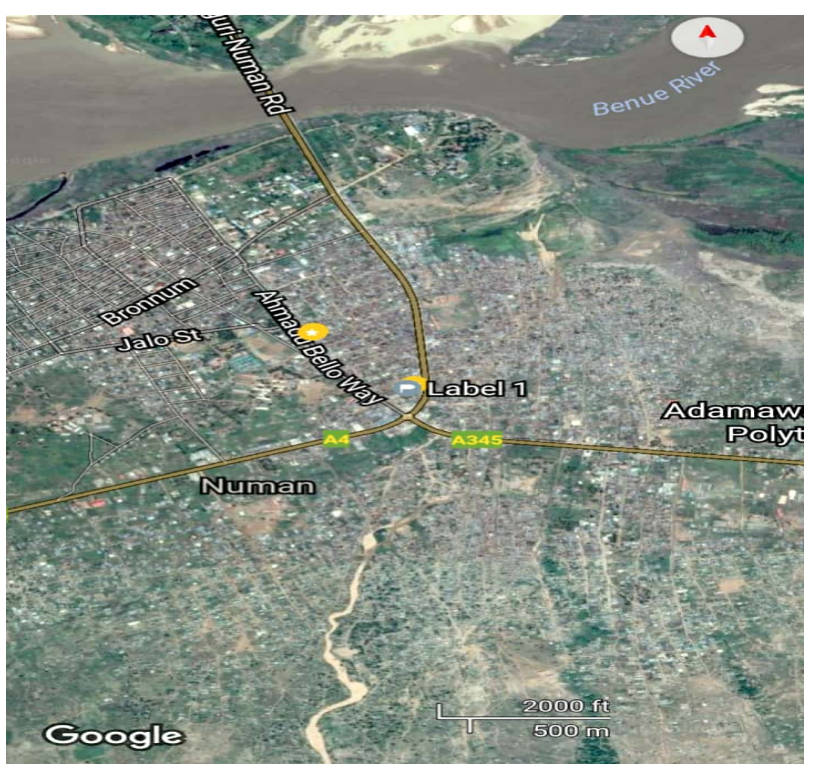

Figure 1. Satellite map of Numan town North Eastern Nigeria. 


\section{Methodology}

Most waste materials have residual energy content. The energy value depends on the type of the waste, its moisture content and the calorific value [1]-[6] and [10]. To determine the energy value of MSW certain analytical procedures was followed (Figure 2).

\subsection{Moisture Content}

The percentage moisture of the MSW samples was determined by weighing the samples into a pre weighed dish and drying the samples in an oven at $105^{\circ} \mathrm{C}$ to a constant weight for some hours, after which it is cooled and then reweighted [16]. This is done according to American Society of Testing and Material Standard (ASTM). The percentage moisture content (MC) is calculated as a percentage loss in weight before and after drying. Equation (1) defines percentage moisture content.

$$
\% \text { Moisture content }=\left(\frac{\text { Wet Weight }- \text { Dry Weight }}{\text { Wet Weight }}\right) \times 100 \%
$$

\subsection{Energy Content of MSW on as Discarded Basis}

Individual waste component energy content was used to determine the composite energy content. Some waste items especially package can, bottled and other

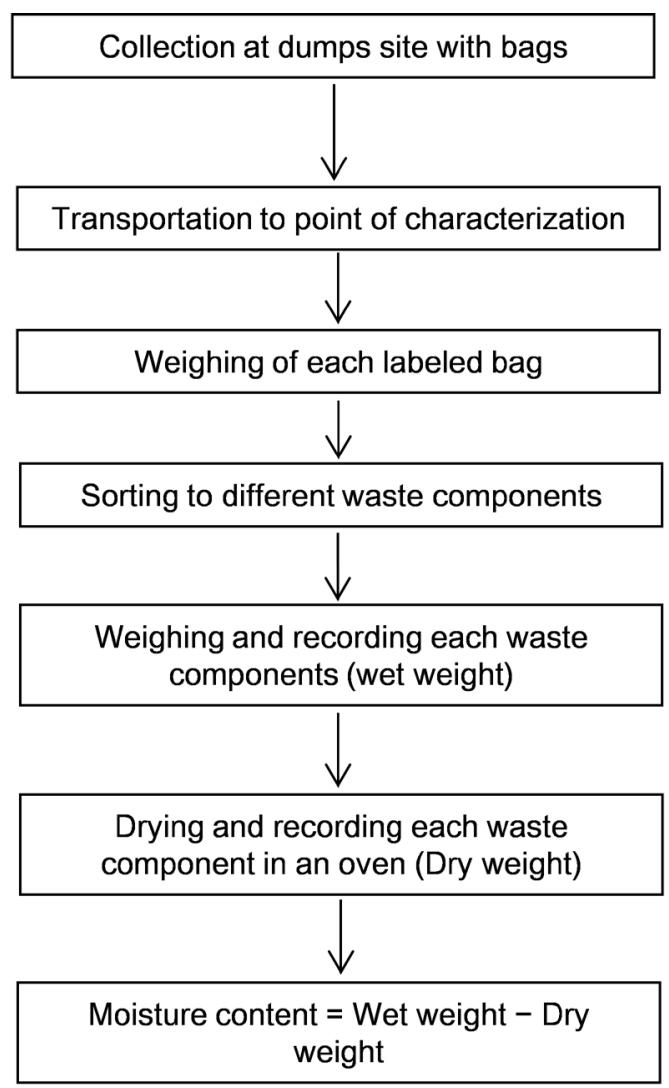

Figure 2. Flow chart process for determination of moisture content. 
disposables products contain labels that show the typical energy content of each waste components. With the typical energy values of each waste component, the total as-discarded energy value of the MSW was computed as follows [17].

The energy content, $E_{C}$ is computed as

$$
E_{C}=\frac{\text { Total Energy as discarded }}{100}
$$

The energy content on dry basis is calculated using

$$
E_{\text {dry }}=E_{\text {discard }}\left(\frac{100}{100-\% \text { moisture }}\right) \mathrm{kJ} / \mathrm{kg}
$$

The energy content on ash-free basis is

$$
E_{\text {dry }}=E_{\text {discard }}\left(\frac{100}{100-\% \text { moisture }-\% \text { ash }}\right) \mathrm{kJ} / \mathrm{kg}
$$

\subsection{Energy Content by Ultimate Analysis of MSW}

Solid waste is a mixture of different components which have their own chemical formula. To carry out an ultimate analysis of MSW the chemical formula of the MSW was obtained. After getting the chemical formula of the solid waste, the Dulong's Formula for estimating energy content of solid waste was then applied on the chemical formula to obtain the heating value of the waste [3].

The chemical formula of solid waste was obtained using the typical fractional elemental composition of solid waste on dry basis shown in Table 1 and then multiplying the dry mass of each waste component by the typical elemental fractional value.

From the computed values, the mass of moisture in the waste sample was determined using (5). The calculated moisture content was converted to Hydrogen and Oxygen using (6). Then add the converted masses of the hydrogen and oxygen to their dry masses in the waste sample to calculate the chemical formula with water as (6b) and (6c).

$$
\text { Moisture Content }=\text { Wet mass }- \text { Dry mass }
$$

Table 1. Typical data on ultimate Analysis of Combustible MSW Percent weight (Dry basis) (After Tchobanoglous, et al. [17]).

\begin{tabular}{ccccccc}
\hline Components & $\mathrm{C}$ & $\mathrm{H}$ & $\mathrm{O}$ & $\mathrm{N}$ & $\mathrm{S}$ & Ash \\
\hline Plastics & 60.0 & 7.2 & 22.8 & - & - & 10.0 \\
Paper & 43.5 & 6.0 & 44.0 & 0.3 & 0.2 & 6.0 \\
Metals & 4.5 & 0.6 & 4.3 & $<0.1$ & - & 90.5 \\
Glass & 0.5 & 0.1 & 0.4 & $<0.1$ & - & 98.9 \\
Mixed food & 48.0 & 6.4 & 37.6 & 2.6 & 0.4 & 5.0 \\
Textiles & 48.0 & 6.4 & 40.0 & 2.2 & 0.2 & 3.2 \\
Polythene & 85.2 & 14.2 & - & $<0.1$ & $<0.1$ & 0.4 \\
\hline
\end{tabular}


Mass of element $=\frac{\text { molecular weight element }}{\text { molecular weight water }} \times$ mass of moisture

Total Mass of $H=$ Mass of $H$ in the moisture + Mass of $H$ in dry sample Similarly,

Total Mass of $O=$ Mass of $O$ in the moisture + Mass of $O$ in dry sample

The molar composition was determined and there after normalized mole ratio. The chemical formula for the waste sample is deduced for the waste with and without water.

The Modified Dulong's formula and the net energy released on combustion, LHV are as stated in (7) and (8) respectively.

$$
\begin{gathered}
\mathrm{HHV} \mathrm{kJkg}{ }^{-1}=337 \mathrm{C}+1419\left(\mathrm{H}_{2}-0.125 \mathrm{O}_{2}\right)+93 \mathrm{~S}+23 \mathrm{~N} \\
\mathrm{LHV}=\mathrm{HHV}-(2.766 \times W) \mathrm{kJ} \cdot \mathrm{kg}^{-1}
\end{gathered}
$$

where, $W=$ moisture content, $2.66 \mathrm{~kg} / \mathrm{g}=$ coefficient of heat requirement for evaporation (Enthalpy of vaporization).

With the calculated energy content (LHV or NCV) and the total waste generation rate the electrical energy output can be determined from [3] as in (9) and (10),

$$
\text { Efficiency } \eta=\frac{\text { Energy output }\left(E_{o}\right)}{\text { Energy input }\left(E_{i}\right)}=\frac{\text { Electrical Energy output }}{\text { Energy input }} \times 100 \%
$$

or

$$
\text { Energy input } E_{i}=\text { Mass flow rate }\left(M_{f}\right) \times \text { Calorific value }(\mathrm{LHV})
$$

With the assumption that the total waste generated is being burnt in an incinerator plant with efficiency $\eta$ and a mass flow rate $M_{f}$ for the purpose of electric energy generation.

Combining (9) and (10) we have the electrical energy output, $E_{o}$ as

$$
E_{o}=\eta \times M_{f} \times \mathrm{LHV}
$$

where $M_{f}$ is

$$
M_{f}=\frac{\text { mass }}{\text { time }}
$$

\section{Results and Discussion}

The study area was divided into divisions/wards so as to have a wide coverage and better representation of the waste streams generated in the entire town. For each division the raw mass of solid waste collected was weighed daily and the result of 30 days average was presented in Table 2.

The waste samples were gathered together in one place and then hand sorted into various waste components. Sand, stones, ash were sieved out of the waste. The waste was found to consist of Paper, Plastics, textiles, polythene, mixed organics, Glass and Metals. Table 3 shows the masses of each waste component with their corresponding percentages by mass. Polythene waste was the most 
Table 2. Average daily waste collected per Division of Numan.

\begin{tabular}{cccc}
\hline Divisions & No of collection points & Average waste collected $(\mathrm{kg})$ & \% Share of the waste \\
\hline Green Village & 2 & 1.67 & 7.47 \\
Gweda Mallam & 3 & 1.83 & 8.18 \\
Angwan Mbulawa & 2 & 1.75 & 7.82 \\
Sabon Peggi & 2 & 4.24 & 18.95 \\
Angwan Sarki & 2 & 2.45 & 10.95 \\
Nassarawo Demsa & 2 & 3.34 & 14.93 \\
Angwan Mission & 2 & 2.16 & 9.66 \\
Abuja & 2 & 3.35 & 14.98 \\
Rafin Sanyi & 2 & 1.58 & 7.06 \\
Total & & 22.37 & 100.00 \\
\hline
\end{tabular}

Table 3. Computed moisture content and total energy of Numan MSW.

\begin{tabular}{cccccccc}
\hline Waste types & $\begin{array}{c}\text { \% Share of the } \\
\text { waste by mass }\end{array}$ & $\begin{array}{c}\text { Wet weight } \\
(\mathrm{kg})\end{array}$ & $\begin{array}{c}\text { Dry weight } \\
(\mathrm{kg})\end{array}$ & $\begin{array}{c}\text { Moisture } \\
\text { mass }(\mathrm{kg})\end{array}$ & $\begin{array}{c}\text { Moisture } \\
\text { content (\%) }\end{array}$ & $\begin{array}{c}\text { Typical energy } \\
\mathrm{kJ} / \mathrm{kg} \text { (as discarded) }\end{array}$ & $\begin{array}{c}\text { Total energy kJ (based } \\
\text { on 100 kg sample) }\end{array}$ \\
\hline Plastics & 10.2 & 0.94 & 0.80 & 0.14 & 14.893 & 32,600 & 332,520 \\
Paper & 9.8 & 0.90 & 0.77 & 0.13 & 14.444 & 16,750 & 164,150 \\
Metals & 6.4 & 0.59 & 0.57 & 0.02 & 3.390 & 700 & 4480 \\
Glass & 9.3 & 0.86 & 0.84 & 0.02 & 2.326 & 150 & 1395 \\
Organic & 24.1 & 2.22 & 1.40 & 0.82 & 36.936 & 18,000 & 433,800 \\
Textiles & 13.2 & 1.22 & 1.01 & 0.21 & 17.213 & 17,450 & 230,340 \\
Polythene & 27.0 & 2.49 & 2.31 & 0.18 & 7.229 & 32,600 & 880,200 \\
Total & 100.0 & 9.22 & 7.70 & 1.52 & MC $=16.486$ & & $2,046,885$ \\
\hline
\end{tabular}

$\mathrm{Mc}=$ Moisture content.

abundant, consisting $27 \%$ of the total waste sorted. Others are Organic $(24.1 \%)$, Plastics (10.2\%), while Textiles and Paper shared (13.2\%) and (9.8\%) with Glass 9.3\% and Metals 6.4\%.

The moisture content for the wastes calculated using (1) from Table 3 was shown in Figure 3. The figure indicated that organic matter has the highest $(38 \%)$ while glass has the least (2\%) moisture content. From Equation (1), the Moisture content of the total average daily MSW was $16.485 \%$.

\subsection{The Energy Content of the MSW}

Using Equation (2) and Table 3, the energy content for the "as discarded" MSW is $20468.85 \mathrm{~kJ} / \mathrm{kg}$. From the moisture content of $16.486 \%$, the energy content on dry basis was calculated using Equation (3) to be $24510.66 \mathrm{~kJ} / \mathrm{kg}$. The energy content for ash free basis assuming ash value of $5 \%$ was also determined using (4) as $26071.65 \mathrm{~J} / \mathrm{kg}$. 


\subsection{Chemical Composition of the MSW Sample}

With Table 1 the fractions of the elemental composition of the various waste components collected are computed and the result is shown in Table 2. From Table 3, the total mass of moisture in the waste sample collected is $1.52 \mathrm{~kg}$.

Using (6a) and Moisture Content reported in Table 4, the converted masses of Hydrogen, $\mathrm{H}$ and Oxygen, $\mathrm{O}$ are: $0.16889 \mathrm{~kg}$ and $1.35111 \mathrm{~kg}$ respectively, while the total masses of $\mathrm{H}$ and $\mathrm{O}$ from 6(b) and 6(c) are: $0.7592 \mathrm{~kg}$ and 2.83058 $\mathrm{kg}$ respectively.

The elemental composition of the waste sample was summarized in Table 5

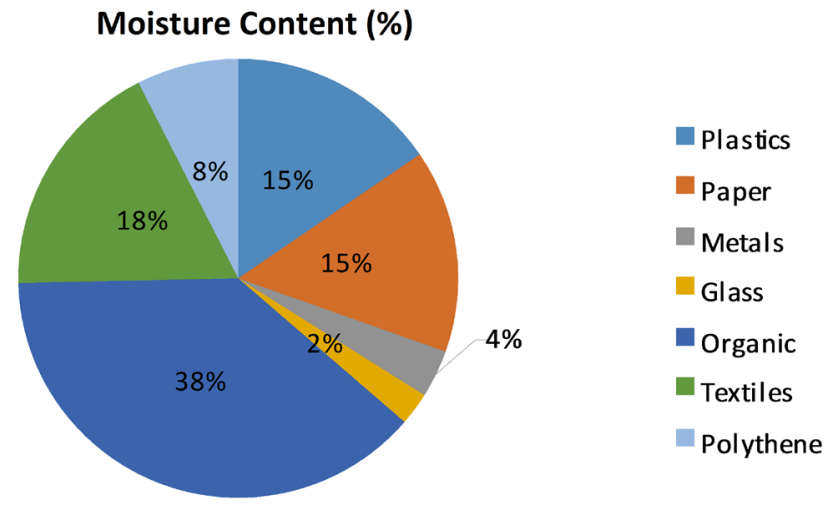

Figure 3. The moisture contents of the respective waste types.

Table 4. Waste composition and elemental fraction values.

\begin{tabular}{|c|c|c|c|c|c|c|c|c|}
\hline $\begin{array}{c}\text { Waste } \\
\text { Components }\end{array}$ & $\begin{array}{c}\text { Wet mass } \\
(\mathrm{kg})\end{array}$ & $\begin{array}{l}\text { Dry mass } \\
(\mathrm{kg})\end{array}$ & $\mathrm{C}$ & $\mathrm{H}$ & $\mathrm{O}$ & $\mathrm{N}$ & $S$ & Ash \\
\hline Plastics & 0.94 & 0.80 & 0.48000 & 0.05760 & 0.1824 & - & - & 0.08000 \\
\hline Paper & 0.90 & 0.77 & 0.33495 & 0.04620 & 0.33880 & 0.00231 & 0.00154 & 0.04620 \\
\hline Metals & 0.59 & 0.57 & 0.02565 & 0.00342 & 0.02451 & 0.00057 & - & 0.51585 \\
\hline Glass & 0.86 & 0.84 & 0.00420 & 0.00084 & 0.00336 & 0.00084 & - & 0.83076 \\
\hline Organic & 2.22 & 1.40 & 0.67200 & 0.08960 & 0.52640 & 0.03640 & 0.00560 & 0.07000 \\
\hline Textiles & 1.22 & 1.01 & 0.48480 & 0.06464 & 0.40400 & 0.02222 & 0.00202 & 0.03232 \\
\hline Polythene & 2.49 & 2.31 & 1.96812 & 0.32802 & - & 0.00231 & 0.00231 & 0.00924 \\
\hline Total & 9.22 & 7.70 & 3.96972 & 0.59032 & 1.47947 & 0.06465 & 0.01147 & 1.58437 \\
\hline
\end{tabular}

Table 5. Approximate chemical formula and mole ratio with and without water.

\begin{tabular}{|c|c|c|c|c|c|c|c|c|}
\hline Element & $\begin{array}{l}\text { Mass without } \\
\text { water }(\mathrm{kg})\end{array}$ & $\begin{array}{l}\text { Mass with } \\
\text { water }(\mathrm{kg})\end{array}$ & $\begin{array}{l}\text { Percentage } \\
\text { by mass (\%) }\end{array}$ & $\begin{array}{l}\text { Molecular } \\
\text { mass }\end{array}$ & $\begin{array}{l}\text { Amount of mole } \\
\text { without water }\end{array}$ & $\begin{array}{c}\text { Amount of } \\
\text { mole with water }\end{array}$ & $\begin{array}{c}\text { Mole ratio } \\
\text { without water }\end{array}$ & $\begin{array}{l}\text { Mole ratio } \\
\text { with water }\end{array}$ \\
\hline $\mathrm{C}$ & 3.96972 & 3.96972 & 43.03 & 12.01 & 0.330535 & 0.330535 & 923.28 & 923.28 \\
\hline $\mathrm{H}$ & 0.59032 & 0.75921 & 8.23 & 1.01 & 0.584475 & 0.751693 & 1632.60 & 2099.70 \\
\hline $\mathrm{O}$ & 1.47947 & 2.83058 & 30.70 & 16.00 & 0.092467 & 0.176911 & 258.29 & 494.16 \\
\hline $\mathrm{N}$ & 0.06465 & 0.06465 & 0.70 & 14.01 & 0.004615 & 0.004615 & 12.89 & 12.89 \\
\hline $\mathrm{S}$ & 0.01147 & 0.01147 & 0.12 & 32.06 & 0.000358 & 0.000358 & 1.00 & 1.00 \\
\hline
\end{tabular}


for the waste collected with and without water also, the molar composition and normalized mole ratio were calculated and presented from which the chemical formula for the waste generated was deduced.

\subsection{The Combustible Energy Content Estimation}

Using Equation (7) and the data in Table 5, the calorific value (HHV) of the waste generated was determined for the chemical composition with water to be $20771.44 \mathrm{~kJ} / \mathrm{kg}$. Also the LHV (the net energy released on combustion) was obtained using (8) as $20767.23 \mathrm{~kJ} / \mathrm{kg}$.

\subsection{The Electricity Generation Potentials}

With the net calorific value calculated, the total waste generated flow rate per day and the assumed plant efficiency, the electrical energy content of the waste were estimated. Using Equation (12) the mass flow rate was $0.5839 \mathrm{~kg} / \mathrm{s}$. The electrical energy recovery potential from the municipal solid waste as stated in (11), at an assumed overall operating efficiency of $25 \%$, was $3031.50 \mathrm{~kJ} / \mathrm{s}(3.0315$ MW). The simulation carried out for different overall efficiencies of the incinerating plant ranging from $15 \%$ to $55 \%$ at the mass flow rate of $0.5839 \mathrm{~kg} / \mathrm{s}$ and heating value of $20767.23 \mathrm{~kJ} / \mathrm{kg}$, reveals a corresponding electrical output of $1818.9 \mathrm{~kW}$ to $6669.29 \mathrm{~kW}$ respectively based on Equation (11).

\section{Conclusions}

This research work revealed that the waste compositions in the study area are heterogeneous. The mixed waste is found to consist of Paper, Plastics, Textiles, Polythene, Mixed organics, Glass and Metals after it is being sorted. In Numan, Polythene waste was the most abundant (27\%) followed by Organic (24.1\%), Plastics (10.2\%), Textiles (13.2\%) and Paper (9.8\%), Glass (9.3\%) and Metals (6.4\%).

Numan MSW having percentage moisture content of $16.49 \%$ indicates that the waste generated can burn easily with high heating value and can be used as a fuel for thermochemical conversion (incineration, pyrolysis or gasification) plant that is technically viable for energy recovery since both values of percentage moisture content fall within the specified range.

The empirical chemical formula for the waste generated in Numan MSW was defined as follows

$$
\begin{array}{ll}
\mathrm{C}_{923.28} \mathrm{H}_{1632.60} \mathrm{O}_{258.28} \mathrm{~N}_{12.89} \mathrm{~S} & \text { without water } \\
\mathrm{C}_{923.28} \mathrm{H}_{2099.70} \mathrm{O}_{494.16} \mathrm{~N}_{12.89} \mathrm{~S} & \text { with water }
\end{array}
$$

The LHV of $20767.23 \mathrm{~kJ} / \mathrm{kg}$ calculated in this study is well above the minimum value. Therefore, the MSW of the study area can be used as a fuel for incineration and for electricity generation. The research also reveals that the energy content value on ash-free dry basis is $20861.48 \mathrm{~kJ} / \mathrm{kg}$. The estimated net power generation per day at an assumed efficiency of $25 \%$ for an incinerating plant is $3031.50 \mathrm{~kW}$. The electrical energy expected ranges between $1400.76 \mathrm{~kW}$ and 
$5136.13 \mathrm{~kW}$. Hence, the electricity potential due to the Numan Municipal solid waste is significant. Therefore, the MSW available has residual or potential energy content that is good enough to be converted to heat or electrical energy via energy recovery processes (an incinerating plant).

\section{Conflicts of Interest}

The authors declare no conflicts of interest regarding the publication of this paper.

\section{References}

[1] Sastry, D.B.S.S.R. (2015) Composition of Municipal Solid Waste-Need for Thermal Treatment in Present Indian Context. http://www.seas.columbia.edu/earth/wtert/sofos/DBSSRS_Article_-_WTE_INDIA_ BRIEF_Revised.pdf

[2] Kadafa, A.A., Latifah, A.M., Abdullah, H.S. and Sulaiman, W.N.A. (2013) Current Status of Municipal Solid Waste Management Practise in FCT Abuja. Research Journal of Environmental and Earth Sciences, 5, 295-304.

[3] Yusuff, A.S., John, W., Okoro, O. and Ajibade, A. (2014) Physio-Chemical Composition and Energy Content Analysis of Solid Waste: A Case Study of Castlereagh District, Northern Ireland. American Journal of Engineering and Technology Research, 2, 1-9.

[4] Linda, S., Mehdi, K. and Lylia, B. (2013) Assessment of Different Methods of Treatment for an Integrated Municipal Waste Management for Algerian City. Management of Environmental Quality: An international Journal, 25, 493-504.

[5] Ujam, A.J. and Eboh, F. (2012) Thermal Analysis of Small-Scale Municipal Solid Waste-Fired Steam Generator: A Case Study of Enugu State, Nigeria. Journal of Energy Technologies and policy, 2, 38-49.

[6] Themelis, N.J., Kim, Y.H. and Brady, M.H. (2002) Energy Recovery from New York City Solid Waste. ISWA Journal: Waste Management and Research, 20, 223-233.

[7] Hassan, A.A., Kenan, J. and Amimul, A. (2015) Environmental Performance and Energy Recovery Potential of Five Processes for Municipal Solid Waste Treatment. Journal of Cleaner Production, 105, 233-240.

[8] Ted, M. (2010) The 2010 ERC Directory of Waste-to-Energy Plants. http://energyrecoverycouncil.org/userfiles/file/ERC_2010_Directory.pdf

[9] Kumar, J.S., Subbaiah, K.V. and Prasada, R.P.V.V. (2010) Waste to Energy-A Case Study of Eluru City, Andhra Pradesh. International Journal of Environmental Sciences, 1, 151-162.

[10] Arthur, O., Mahir, S., Karoli, N., Geoffrey, J. and Peter, M. (2014) Energy Recovery Routes from Municipal Solid Waste, a Case Study of Arusha-Tanzania. Journal of Energy Technologies and Policy, 4, 1-7.

[11] Kuleape, R., Cobbina, S.J., Dampare, S.B., Duwiejuah, A.B., Amoako, E.E. and Asare, W. (2014) Assessment of the Energy Recovery Potentials of Solid Waste Generated in Akosombo, Ghana. African Journal of Environmental Science and Technology, 8, 297-305. https://doi.org/10.5897/AJEST2014.1663

[12] Muhammad, T.B., Alkasim, A. and Muhammad, B.A. (2014) Estimation of Moisture Content of Household Solid Waste in Some Selected Areas of Jimeta Town. International Journal of Scientific and Engineering Research, 5, 430-433. 
[13] Ogwueleka, T.C. (2009) Municipal Solid Waste Characteristics and Management in Nigeria. Iranian Journal of Environment and Health Science Engineering, 6, 173-180.

[14] Zainab, A.B. and Hijab, M. (2013) Survey of Municipal Solid Waste in Jimeta-Yola, Northeastern Nigeria. International Journal of Scientific and Engineering Research, 4, 1-8.

[15] Ethiopian Public Health Training Initiative EPHTI (2004) Lecture Notes on Solid Waste Management. https://www.cartercenter.org/resources/pdfs/health/ephti/library/lecture_notes

[16] Obid, T., Jan, D. and Wojciech, N. (2015) Catalytic Energy Production from Municipal Solid Waste Biomass: Case Study in Perlis-Malaysia. World Journal of Environmental Engineering, 3, 7-14.

[17] Tchobanoglous, G., Theiman, H. and Eliassen, R. (1977) Solid Wastes Engineering Principles and Management Issues. McGraw-Hill, New York. 